\title{
In Memoriam John Wilfrid Linnett
}

Professor John Wilfrid Linnett, Ph.D., F.R.S., who has been a coeditor of Theoretica Chimica Acta from the date of its foundation, died on November 7, 1975, in his club "The Athenaeum", London.

John Wilfrid Linnett published 260 papers, among them many of a theoretical nature; a number of those papers were devoted to the theory of chemical bonding, and one of the two books he wrote, Wave Mechanics and Valency, shows his interest in this field. He was one of the most successful scientists in his country.

By mentioning a few details, I shall try to give a brief summary of his life:

He was born in 1913 and married in 1947. From 1939 to 1945 he was a Junior Research Fellow at Balliol College, Oxford, and from 1945 to 1965 Fellow of Queen's College, Oxford. During the last ten years of his life, John Wilfrid Linnett was Professor of Physical Chemistry in Cambridge.

Among the numerous honours that were bestowed on him, it should above all be mentioned that Professor Linnett was a Fellow of the Royal Society from 1955 on. In 1966, he was given the Award of Merit of the City of Coventry. In 1965, he was elected Fellow of the New York Academy of Sciences (Life Member).

During the last years of his life, Professor Linnett was also busy in the activities of the large scientific societies. From 1971 to 1973, he was President of the Faraday Division of the Chemical Society, and in April 1975 became President Elect of the Chemical Society.

Theoretica Chimica Acta is grateful for his faithful cooperation. $\mathrm{He}$ acquired high esteem also as a co-editor of our journal.

Hermann Hartmann 